\title{
Skill or will? The respective contribution of motivational and behavioural characteristics to secondary school students' reading comprehension
}

\author{
Van Ammel Kimª, Aesaert Koen ${ }^{b}$, De Smedt Fienª, Van Keer Hilde \\ ${ }^{a}$ Department of Educational Studies, Ghent University, Ghent, Belgium \\ ${ }^{\mathrm{b}} \mathrm{C}$ tr Educ Effectiveness \& Evaluat, Katholieke Univ Leuven, Leuven, Belgium
}

\begin{abstract}
Background: A significant number of secondary school students struggle with comprehending texts proficiently. Enhancing their reading comprehension requires knowledge about how this ability is related to various behavioural and motivational characteristics. The central aim of this study was therefore to investigate the (in)direct relationships between $9^{\text {th }}$-grade students' motivational (i.e., reading motivation and reading self-concept) and behavioural characteristics (i.e., reading strategy use, reading engagement, and reading frequency) and their reading comprehension. Furthermore, differential relationships across educational tracks are investigated.
\end{abstract}

Methods: A total of $24859^{\text {th }}$-grade students completed a standardised reading comprehension test and an online questionnaire to operationalise the motivational and behavioural reading variables. Data were analysed using multigroup structural equation modelling to study potential differential relationships across educational tracks (i.e., academic, technical, and vocational track).

Results: Motivational and behavioural characteristics were directly related to students' reading comprehension. Moreover, the relationships between motivational characteristics and reading comprehension were mediated by behavioural characteristics. As to differences across educational tracks, not all of the relationships were corroborated similarly for each track.

Conclusion: Generally, the results emphasise the importance of considering the "bigger picture", taking into account the respective contribution of both behavioural and motivational characteristics to secondary school students' reading comprehension and concurrently considering differences across educational tracks. 


\section{Implications for Practice}

What is already known about this topic:

- Both motivational and behavioural characteristics are related to students' reading comprehension.

- The relationship between reading motivation and reading comprehension is mediated by students' reading behaviour.

What this paper adds:

- It unravels the respective contribution of both motivational and behavioural characteristics to reading comprehension for secondary school students.

- It uncovers the differential relationships between motivational and behavioural characteristics and reading comprehension for different educational tracks.

Implications for theory, policy, or practice:

- Research and theory regarding the relationship between motivational and behavioural characteristics and secondary school students' reading comprehension should consider differential relationships depending on students' educational track.

- Future research concerning the effectiveness of reading comprehension instruction and educational interventions designed to improve reading comprehension could take into account both motivational and behavioural characteristics and specific attributes based on students' educational track. 


\section{Problem Statement}

In the context of $21^{\text {st }}$-century skills and lifelong learning (European Commission, 2006), reading comprehension is a key competence contributing to both students' academic success and success beyond school (Taboada et al., 2009). In this respect, schools are entrusted with the crucial task of developing students' skills in reading comprehension. In light of this, schools and teachers should be aware of student characteristics associated with reading comprehension. Prior research has already investigated this extensively, confirming that motivational as well as behavioural characteristics are important correlates of reading comprehension (e.g., Guthrie et al., 1999; Wang \& Guthrie, 2004). However, some issues remain unresolved.

First, secondary school students are increasingly expected to obtain knowledge from texts (Rogiers et al., 2019). Strikingly, a growing number of adolescents do not possess age-appropriate reading skills (OECD, 2019b). Consequently, several researchers have called for more reading comprehension research in secondary schools, in comparison to the prior dominant focus on primary school students (Retelsdorf et al., 2011; Wolters et al., 2014). Second, few studies have investigated the contribution of motivational and behavioural characteristics to secondary school students' reading comprehension from a comprehensive point of view. Most studies have focused on either motivational or behavioural characteristics without considering the indirect pathways in which these characteristics might relate to reading comprehension (e.g., Denton et al., 2015; Katzir et al., 2009). In this respect, Schiefele et al. (2012) have stated that the mediating role of reading behaviour between reading motivation and achievement remains to be clarified. Third, in many countries, secondary school students are divided between separate educational tracks. Recently there has been growing interest in studying differences between these tracked groups (Dockx et al., 2019). However, research considering educational tracks in relation to the (respective) contribution of motivational and behavioural characteristics to reading comprehension remains very scarce.

To deal with these issues, the present study addresses four research questions: 
1. Are motivational variables (i.e., reading self-concept, autonomous and controlled reading motivation) directly related to $9^{\text {th }}$-grade students' reading comprehension?

2. Are behavioural variables (i.e., reading strategy use, reading engagement, reading frequency) directly related to $9^{\text {th }}$-grade students' reading comprehension?

3. Are the relationships between motivational variables and $9^{\text {th }}$-grade students' reading comprehension mediated by behavioural variables?

4. Are the (in)direct relationships between motivational and behavioural variables and $9^{\text {th }}$-grade students' reading comprehension different across educational tracks?

\section{Theoretical and Empirical Background}

\section{Reading Comprehension}

Reading comprehension refers to the ability to gain meaning from what is read. This demonstrates a complex (meta-)cognitive process encompassing both low-level (word-level) and high-level (text-level) text-processing activities (McNamara \& Magliano, 2009). Especially in the context of secondary education, high-level processes should receive prominent focus. This focus on high-level text processing is indubitably related to the concept of knowledge in our knowledge-based society. Knowledge needs not only to be remembered, as it is crucial to understand, criticise, and reflect on knowledge as well (Fredricks et al., 2004). Moreover, in the context of lifelong learning, individuals should be able to expand their knowledge, skills, and strategies in various contexts (European Commission, 2006). Further, in secondary education students are expected not only to be able to read texts but also to learn from them (Wharton-McDonald \& Swiger, 2009). This requires high-level text comprehension (Rogiers et al., 2019). Correspondingly, the focus in the present study will be on high-level text comprehension processes of secondary school students. 
The Respective Contribution of Motivational and Behavioural Characteristics to Reading

\section{Comprehension}

\section{Direct Contribution of Motivational Characteristics}

Research indicates that motivational characteristics (i.e., reading self-concept, autonomous and controlled reading motivation) contribute to reading comprehension. First, reading self-concept appears to be positively associated with reading comprehension (e.g., Katzir et al., 2009; Taboada et al., 2009). Reading self-concept refers to "students' overall self-perception as a reader, including one's sense of competence and the role ascribed to reading as a part of one's personal identity" (Conradi et al., 2014, Table 5). Second, reading motivation is positively related to reading comprehension. However, different conceptualisations of reading motivation have been adopted in the literature. Self-determination theory (SDT) is promising in terms of assessing qualitatively different types of motivation (Conradi et al., 2014; De Naeghel et al., 2016; Ryan \& Deci, 2020). SDT distinguishes autonomous and controlled reading motivation. Autonomous reading motivation refers to reading because of the enjoyment of reading itself (i.e., intrinsic regulation) or the relevance readers attach to reading (i.e., identified regulation). Controlled reading motivation refers to reading because of external demands, rewards, or expectations (i.e., external regulation) or because of internal demands, reflected in feelings of guilt, pride, fear, or shame (i.e., introjected regulation). Autonomous reading motivation is expected to be positively related to reading comprehension, whereas reading for controlled reasons is expected to be negatively related (De Naeghel et al., 2012; Ryan \& Deci, 2020; Vansteenkiste et al., 2005).

\section{Direct Contribution of Behavioural Characteristics}

Next, in addition to motivational characteristics, students' reading behaviour contributes to their reading comprehension as well (De Naeghel et al., 2012). The behavioural characteristics included in this study reflect both the quality (i.e., reading strategy use and reading engagement) and the quantity (i.e., reading frequency) of students' reading behaviour. Reading strategies are defined 
as "deliberate, goal-directed attempts to control and modify the reader's efforts to decode text, understand words, and construct meanings of text" (Afflerbach et al., 2008, p. 368). Reading strategy use is considered an important predictor of reading comprehension (e.g., Denton et al., 2015; Lau, 2006; Taboada et al., 2009). Following the research of Mokhtari and Reichard (2002), the present study distinguishes between global, support, and problem-solving reading strategy use. Global reading strategy use assists in the global understanding of texts. Support reading strategies make use of external aids or materials. Problem-solving reading strategies are used when a reader is confronted with comprehension difficulties. Previous studies particularly confirmed the positive association of global and problem-solving reading strategy use with reading comprehension. A negative or nonsignificant relationship has been found for support reading strategy use (Cantrell \& Carter, 2009).

Next to reading strategy use, higher levels of reading engagement will result in more proficient reading comprehension (Guthrie et al., 2004). Engagement refers to the quality of students' involvement during reading, encompassing both a behavioural (e.g., attention, effort) and an emotional component (e.g., positive emotion) (Fredricks et al., 2004). Finally, it is assumed that students who read frequently are more successful readers (De Naeghel et al., 2012; Mol \& Bus, 2011). In the present study, reading frequency in a recreational context is included since this appears to be more strongly related to comprehension than reading frequency in an academic context (Schiefele et al., 2012).

\section{Indirect Contribution of Motivational Characteristics, Mediated by Behavioural Characteristics}

Furthermore, behavioural characteristics mediate the relationship between motivational characteristics and reading comprehension. As to reading self-concept, its relationship with reading comprehension is supposed to be mediated by reading engagement, reading frequency (De Naeghel et al., 2012; Skinner et al., 1990) and reading strategy use. Concerning mediation via reading engagement and reading strategy use, the theoretical work of Paris et al. (1983) indicates that 
students' reading self-concept influences their decision-making about how to invest time and effort to achieve a goal, thus affecting strategy use during reading. This positive relationship between students' reading self-concept and strategy use has been confirmed in prior research, pointing to a significant correlation with metacognitive strategy use (Roeschl-Heils et al., 2003). However, evidence for secondary school remains scarce (Retelsdorf et al., 2014).

As to reading motivation, reading engagement positively mediates the relationship between autonomous reading motivation and comprehension (De Naeghel et al., 2012; Wigfield et al., 2008). However, results relating to controlled reading motivation have still been inconclusive (De Naeghel et al., 2012). Considering the mediation via reading frequency, both autonomous and controlled reading motivation are positively related to reading frequency (De Naeghel et al., 2012; Klauda \& Guthrie, 2014; Mol \& Bus, 2011). However, reading frequency's mediating role between reading motivation and comprehension has not yet been extensively supported in the empirical research in secondary education (Schiefele et al., 2012). Regarding reading strategy use, Schiefele et al. (2012) reported that the related concept of intrinsic reading motivation is positively associated with strategy use, whereas a negative or nonsignificant relation is found for extrinsic motivation. Nonetheless, more research is still needed to confirm these relationships and to study the mediating role of reading strategy use in the relationship between reading motivation and comprehension, especially from the SDT literature distinguishing autonomous and controlled reading motivation.

The hypotheses are visually presented in Figure 1.

$<<$ insert Figure 1 about here $>>$

In sum, positive direct contributions of reading self-concept (hypothesis 1), autonomous reading motivation (hypothesis 2), global and problem-solving reading strategy use (hypothesis $4 a-c$ ), reading engagement (hypothesis 5), and reading frequency (hypothesis 6) to reading comprehension are expected. In contrast, the contribution of controlled reading motivation to reading comprehension (hypothesis 3 ) is anticipated to be negative. The hypothesis concerning support 
reading strategy use is studied exploratively (hypothesis $4 b$ ). Regarding the indirect relationships, the relationship between reading self-concept and reading comprehension is supposed to be positively mediated by reading engagement (hypothesis $7 d$ ) and reading frequency (hypothesis 7e). The hypothesis concerning the mediation via reading strategy use (hypothesis $7 a-c$ ) is studied exploratively. Furthermore, the relationship between autonomous reading motivation is expected to be positively mediated by reading engagement (hypothesis $8 d$ ). Mediation via reading strategy use (hypothesis $8 \mathrm{a}-\mathrm{c}$ ) and reading frequency (hypothesis $8 e$ ) are explored. Finally, we explored the extent of mediation in the relationship between controlled reading motivation and reading comprehension (hypothesis 9a-e).

\section{Differences Between Educational Tracks}

In various educational systems around the globe, upper secondary school students are placed in different educational tracks offering different educational programmes. Commonly, a distinction is made between general and vocational educational programmes (OECD, 2019a). In Flanders, four educational tracks are offered to students (i.e., academic, technical, arts, vocational). The academic track involves academic training and primarily prepares for higher education studies. The technical track encompasses both academic and practical training and prepares for both further studies in higher education or outflow to the labour market. The arts track focusses on teaching artistic skills and equally prepares for both further studies in higher education or outflow to the labour market. The vocational track involves practical training and primarily has a labour-market orientation. Reading comprehension, self-concept, intrinsic motivation, interest, enjoyment, strategy knowledge and recreational reading frequency are demonstrated to be lower for students in the technical and especially in the vocational track. These differences could result in differential relationships between students' motivational and behavioural characteristics on the one hand and their reading comprehension on the other hand. With the exception of the work of Kozminsky and Kozminsky 
(2001), Retelsdorf et al. (2011), and Schaffner et al. (2016), this issue has only received limited attention in the literature. Moreover, the results remains inconclusive.

\section{Method}

\section{Sample and Procedure}

A total of $24859^{\text {th }}$-grade students ( $46 \%$ boys, $54 \%$ girls) from 194 classes in Flanders (i.e., the Dutch-speaking part of Belgium) participated. Students' ages ranged from 12 to 18 years $(M=15.06$, $S D=0.61)$. Regarding their educational track, respectively $52 \%(n=1294), 32 \%(n=782)$, and $16 \%(n$ $=409)$ participated in the academic, technical, and vocational track. Eighteen per cent $(n=442)$ of students reported that their mother had not been born in Belgium. The sample is representative for the Flemish community as to students' gender (population; 51\% boys, $49 \%$ girls), track (population; $48 \%$ academic track, $29 \%$ technical track, $23 \%$ vocational track), and mothers' country of birth (population; 22\% not born in Belgium) (Department of Education and Training, 2019). Students in the art track are not included in the present study because in comparison with the other tracks, only a very small proportion of students follow this track.

Data were gathered in authentic classroom settings, during two 50-minute periods. The first period students completed part 1 of a paper-and-pencil reading comprehension test. During the second period, students completed part 2 of the comprehension test ( 25 minutes) and an online questionnaire (25 minutes).

\section{Instruments}

\section{Reading Comprehension}

Reading comprehension performance was assessed using a modified version of a standardised expository reading comprehension test composed by the Dutch Centre of Educational Measurement CITO (CITO B.V., 2013). The test consisted of seven expository texts with 46 binary scored multiple-choice items ( 0 = incorrect; 1 = incorrect $)$. Each multiple-choice question entailed 
four choices. The questions aimed at measuring students' understanding of the text (processing information explicitly presented in the text), text interpretation (interplay of processing and linking text-based and knowledge-driven information, also referred to as inferencing), and text-based reflection (contemplative, evaluative, and critical view of texts). Text and questions were simultaneously available, and students had a maximum of 70 minutes to complete the test. Validity and reliability analyses of the test were conducted based upon classical test and item response theory (IRT). Additionally, all items were screened for differential item functioning for educational tracks. The empirical reliability, the IRT equivalent for the alpha reliability (Adams, 2005), was found to be good (.79).

\section{Motivational and Behavioural Characteristics}

Reading self-concept was measured using five items based on the PIRLS 2006 reading selfconcept subscale (Martin et al., 2007). Reading motivation was measured using the SRQ-reading motivation questionnaire (De Naeghel et al., 2012). Students rated their reading engagement through five items tapping into their attention, effort, verbal participation, persistence, and positive emotion in reading activities (Reeve et al., 2004). Reading frequency was measured using a single item based on the PIRLS 2006 student questionnaire (Martin et al., 2007) and referring to both online and offline recreational reading. Based on the MARSI-R, the self-perceived use of 14 reading strategies was tapped into (Mokhtari et al., 2018), sorted into three categories. Mokhtari et al. recently revised their original instrument MARSI (Mokhtari \& Reichard, 2002). MARSI-R measures the same constructs as MARSI, and the structural, external, and generalisability aspects of validity have been confirmed. An overview of the format, answer options, number of items, along with an example item are presented in Table 1.

$<$ insert Table 1 about here $>$

Information about the confirmatory factor analysis, measurement invariance related to educational track, and internal consistency is presented in Table 2. The CFA model for reading 
engagement showed excellent fit measures (CFI $=.96, \mathrm{RMSEA}=.09$, SRMR $=.03)$. However, strong measurement invariance across educational tracks was not corroborated. Therefore, we excluded one item to ensure strong measurement invariance (effort: "I am not very active while reading ...- I am very active while reading ..."). Based on these four items, CFA still showed excellent fit measures, as presented in Table 2 .

$<<$ insert Table 2 about here $>>$

\section{Data Analysis}

Multigroup structural equation modelling analysis (MG-SEM) was used to analyse relationships between motivational and behavioural characteristics and students' reading comprehension, taking into account potentially differential relationships across educational tracks. All analyses were performed using the R-packages Lavaan (Rosseel, 2010) and semTools (Jorgensen, 2018) and the programme MLwiN. Since data were not completely normally distributed (skewness ranging from -0.73 to .98 and kurtosis ranging from -1.43 to .75 ), robust maximum-likelihood estimation method was used with a Satorra-Bentler-scaled chi-square statistic. Additionally, the standard errors and fit statistics were adjusted according to the clustered data (i.e., students into classes) (Muthén \& Satorra, 1995; Rosseel, 2010; Stapleton, 2006).

\section{Results}

\section{Descriptive Statistics}

Total and descriptive statistics per educational track are presented in Table 3. Differences between educational tracks were encountered on all scales.

$<$ insert Table 3 about here $>$

Correlations between variables are presented in Table 4. Correlations per educational track are presented in Appendix A. Correlations range from .03 to .59 , indicating that including multiple independent variables in a model will not cause multicollinearity problems. 
$<<$ insert Table 4 about here $>>$

\section{MG-SEM}

To analyse the respective contribution of motivational and behavioural characteristics to reading comprehension across educational tracks, two MG-SEM models were compared. In model 1 , factor loadings and intercepts were forced to be equal across groups. In model 2, factor loadings, intercepts, and regression coefficients were forced to be equal across groups. The results revealed significant differences between models 1 and 2. More particularly, a significant different loglikelihood value $\left(\Delta \chi^{2}=600.61(46), p<.001\right)$ was found, indicating a better model fit for model 1 . This implies that a model with differential relationships across educational tracks (model 1 ) fits the data better than the model without differential relationships across educational tracks (model 2). In view of further analysing the differences in the relationships across tracks, model 2 was adjusted by means of allowing each regression coefficient to vary separately across groups. The log-likelihood values of these adjusted models 2 were compared with the log-likelihood value of the original model 2. The difference between both log-likelihood values has a chi-square distribution with two degrees of freedom, adjusted based on the scaling correction factor for the Sattora-Bentler correction (Satorra \& Bentler, 2001). A significant difference between these models indicates a significant difference across educational tracks for the specific regression coefficient that was allowed to vary. Using this procedure, it was possible to test each regression for significant differences across educational tracks. Results are displayed in Table 5.

$<$ insert Table 5 about here $>>$

Results of the MG-SEM are visually presented in Figure 2. Significant differences in the relationships between variables across educational tracks are presented by separate regression coefficients and dotted lines. Nonsignificant regressions were not included in the final model. Regression coefficients presented in this figure are standardised. The coefficient of determination $\mathrm{R}^{2}$, which equals the proportion of explained variance (Kline, 2012), is separately included for all 
educational tracks ( $R^{2}$ academic $/ R^{2}$ technical $/ R^{2}$ vocational). The final model fit was acceptable $(C F I=.88$,

RMSEA $=.05$, SRMR $=.08)$.

$<<$ insert Figure 2 about here $>>$

The indirect relationships between motivational characteristics and reading comprehension, mediated by behavioural characteristics, were investigated based on the Sobel test (Sobel, 1986). The results are displayed in Table 6. Indirect relationships that involve nonsignificant paths (see Figure 2) were not included in this analysis because both direct paths need to be significant to generate mediation (Kline, 2012).

$<<$ insert Table 6 about here $>>$

\section{Discussion}

As presented in the hypothesised model (see Figure 1), both motivational and behavioural characteristics were related to $9^{\text {th }}$-grade students' reading comprehension. Furthermore, behavioural characteristics mediated the relationships between motivational characteristics and reading comprehension. However, the complete picture is more complex than hypothesised, and not all relationships were similarly corroborated for each track. Due to the extensive number of hypotheses, a selection of the most salient findings are subsequently discussed below.

\section{Direct Contribution of Reading Motivation}

As to differential relationships across tracks concerning the direct contribution of reading motivation to reading comprehension, previous studies reported contrasting results. Schaffner et al. (2016) presented a direct contribution of intrinsic reading motivation to reading comprehension exclusively for academic students, and Retelsdorf et al. (2011) reported no differential contributions. As to our results, for students on the technical and especially the vocational track, there was a strong positive direct contribution of autonomous reading motivation to reading comprehension and a strong negative direct contribution of controlled reading motivation. For students on the academic 
track, there was no direct contribution of autonomous reading motivation and a small negative contribution of controlled reading motivation. Future studies are needed to provide more insight into these conflicting findings.

\section{Direct Contribution of Behavioural Characteristics}

\section{Reported Reading Strategy Use}

Differential results were obtained for the different categories of reading strategies and across different educational tracks. Reported problem-solving reading strategy use was positively related to reading comprehension, and this was confirmed for students in all three tracks. Reported global reading strategy use was positively related to reading comprehension as well, however, exclusively for vocational-track students. In contrast, based on the study of Kozminsky and Kozminsky (2001), we expected reading strategy use to be more strongly related to reading comprehension for academictrack students. Kozminsky and Kozminsky (2001) included a measure of general knowledge and found strong correlations between general knowledge and reading comprehension for vocational students. The relationship between reading strategy use and comprehension in our study might thus be overestimated since no measure of general knowledge was included. Furthermore, although the positive contribution of reported problem-solving reading strategy use to reading comprehension was corroborated for students in all three tracks, this relationship was stronger for vocational-track students. In combination with vocational students' lower reported use of global and problem-solving reading strategies (see Table 3), this highlights the need to focus on building and expanding vocational students' repertoire of reading comprehension strategies (Rogiers et al., 2020).

\section{Reading Engagement}

Hinging on the findings of De Naeghel et al. (2012) and Wigfield et al. (2008), we hypothesised reading engagement to be positively related to reading comprehension. However, this was only confirmed for technical-track students. For this group, the quality of reading activities (i.e., reading engagement) seemed to be more important than the quantity (i.e., reading frequency). The 
nonsignificant contribution of reading engagement to reading comprehension for academic- and vocational-track students is puzzling. This might be related to the aims of this study (i.e., studying differential relationships across educational tracks). Previous studies would possibly come to different conclusions after equally including the possibility of these differential relationships. Furthermore, we measured students' reading engagement by means of student self-reports instead of using teachers' reports of student engagement during reading, which is mainly adopted (e.g., Reeve et al., 2004).

\section{Reading Frequency}

As to the relation between reading frequency and comprehension, we found striking differences between educational tracks. For academic-track students, reading frequency was positively related to reading comprehension. In contrast, for technical- and vocational-track students, this relationship was negative. The reasoning of Guthrie et al. (1999) and Schaffner et al. (2016) might give insight into this finding. More particularly, students in technical and vocational track might not read challenging expository texts as frequently as academic-track students. The quality of their recreational reading might thus partially explain these surprising findings.

\section{Indirect Contribution of Motivational Characteristics, Mediated by Behavioural Characteristics}

\section{Indirect Contribution of Reading Self-Concept: The Mediating Role of Reported Support Reading}

\section{Strategy Use}

Based on the theoretical work of Paris et al. (1983), we expected that students' decisions on how to invest time and effort during reading (e.g., their reading strategy use) would be related to their self-concept. Our study confirms this hypothesis: reading self-concept was negatively related to reported support reading strategy use. In other words, students who feel competent as readers reported using fewer support reading strategies. They might not feel the need to use such support strategies since these positive feelings of competence prevent them from the need of using external 
aids. This lower reported use of support reading strategies was consequently related to higher reading comprehension, resulting in a significant positive indirect relationship.

Indirect Contribution of Reading Motivation: The Mediating Role of Reported Reading Strategy Use

In general, our results strengthen the value of stimulating students' autonomous reading motivation (Ryan \& Deci, 2020) since in contrast to controlled reading motivation, students' autonomous motivation positively contributed to all behavioural characteristics and to reading comprehension. Remarkably, one exception can be noted. In addition to autonomous reading motivation, controlled reading motivation was positively related to reported reading strategy use as well. This is in conflict with the results of Schiefele et al. (2012) which present a negative contribution of the related concept of extrinsic reading motivation to strategy use. These results are puzzling and might be explained by specific characteristics of secondary school students. Their autonomous reading motivation declines after entering adolescence (De Smedt et al., 2020). Therefore, this might not be sufficient to stimulate their reading strategy use, resulting in a stronger and positive contribution of controlled reading motivation.

\section{Indirect Contribution of Reading Motivation: The Mediating Role of Reading Frequency}

Autonomous motivation offered a strong positive contribution to reading frequency for students in all three tracks. On the other hand, controlled reading motivation was negatively related to students' reading frequency, implying that reading more for controlled reasons elicits less recreational reading. Conversely, De Naeghel et al. (2012) found controlled reading motivation to be positively related to upper primary school students' reading frequency. These differential findings highlight the need to differentiate between age groups and to consider how feelings of external and internal pressure to read might play a different role in children versus youngsters and in primary versus secondary school contexts. On the other hand, the results of the review of Schiefele et al. (2012) are in line with our results, indicating that when studying intrinsic and extrinsic motivational constructs in the same statistical model, extrinsic motivation is negatively related to reading 
frequency. Notwithstanding the fact that their review departed from another theoretical conceptualisation of reading motivation, parallels with the present study can be drawn. In their discussion Schiefele et al. (2012) suggested that this might be due to a reciprocal suppression based on the high correlation between intrinsic and extrinsic motivation. In the present study, however, the correlation between autonomous and controlled motivation was only moderate $(r=.21)$, meaning that this explanation does not apply to the present study.

\section{Limitations and Suggestions for Future Research}

The limitations of this study should be mentioned. First, regarding reading strategy use, only students' self-reported reading strategy use was included, although self-reports have several limitations. Studies have shown that self-reports are not necessarily a good reflection of students' actual strategy use, as measured using on-line instruments (Bråten et al., 2020). The use of on-line measures (e.g., think-aloud, traces, eye movements) could result in a more in-depth and accurate view of students' reading strategy use and further guide the explanation of the findings (Bråten et al., 2020; Merchie \& Van Keer, 2014; Veenman, 2011). Second, only the quantity of recreational reading was measured by querying reading frequency. However, mapping the quality of students' recreational reading materials might offer additional insights. In this respect, further research could, for instance, focus on the type of texts students on different educational tracks read during their free time (Jerrim et al., 2020). Third, no control measure for prior achievement was adopted, which could result in an overstating of the relationships between behavioural and motivational characteristics and reading comprehension (Becker et al., 2010). Adopting a measure of prior achievement is a crucial guideline for future research that aims to replicate our findings. Fourth, additional behavioural and motivational variables could be adopted, for example a measure of general knowledge (Kozminsky \& Kozminsky, 2001). Finally, future studies taking into account possible differential relationships across tracks are needed to gain insight into conflicts between results of this study and previous studies investigating these differential relationships. 


\section{Conclusion}

This study contributes to the research, policy, and practice related to reading comprehension in several ways. The results clearly underline the importance of considering the "bigger picture". Students' reading self-concept, motivation, strategy use, engagement, and frequency are all separately related to reading comprehension. However, they are also related to one another in complex ways (Guthrie et al., 1999). Additionally, several differences in the relationship between these characteristics across educational tracks are encountered. Therefore, taking into account differences across educational tracks is a promising guideline for future studies (Mol \& Jolles, 2014). Considering the value of this study in light of policy and practice, the results might guide the exploration of how behavioural and motivational components enhance reading comprehension instruction and interventions (e.g., Wigfield et al., 2008). What this research indicates is that differentiated instruction, depending on students' educational track, might be beneficial, as also previously argued by Kozminsky and Kozminsky (2001). This is especially the case for the vulnerable group of vocational students, a group of readers who not only struggle with reading comprehension, but generally are less autonomously motivated to read, have a lower reading self-concept, read less during their free time, and are less engaged during reading (see Table 3, OECD, 2019b). Therefore, designing and implementing reading comprehension instruction specifically for this group of students would be an important direction for future research. 


\section{References}

Adams, R. J. (2005). Reliability as a measurement design effect. Studies in Educational Evaluation, 31(2-3), 162-172. https://doi.org/10.1016/j.stueduc.2005.05.008

Afflerbach, P., Pearson, P. D., \& Paris, S. G. (2008). Clarifying differences between reading skills and reading strategies. The Reading Teacher, 61(5), 364-373. https://doi.org/10.1598/RT.61.5.1

Becker, M., McElvany, N., \& Kortenbruck, M. (2010). Intrinsic and extrinsic reading motivation as predictors of reading literacy: A longitudinal study. Journal of Educational Psychology, 102(4), 773-785. https://doi.org/10.1037/a0020084

Bentler, P. M. (2009). Alpha, dimension-free, and model-based internal consistency reliability. Psychometrika, 74(1), 137-143. https://doi.org/10.1007/s11336-008-9100-1

Bråten, I., Magliano, J. P., \& Salméron, L. (2020). Concurrent and task-specific self-reports. In D. L. Dinsmore, L. K. Fryer, \& M. M. Parkinson (Eds.), Handbook of strategies and strategic processing: Conceptualization, intervention, measurement, and analysis (1st ed.). Routledge. https://doi.org/10.1017/СBO9781107415324.004

Browne, M. W., \& Cudeck, R. (1992). Alternative ways of assessing model fit. Sociological Methods \& Research, 21(2), 230-258. https://doi.org/https://doi.org/10.1177/0049124192021002005

Cantrell, S. C., \& Carter, J. C. (2009). Relationships among learner characteristics and adolescents' perceptions about reading strategy use. Reading Psychology, 30(3), 195-224. https://doi.org/10.1080/02702710802275397

Cheung, G. W., \& Rensvold, R. B. (2002). Evaluating goodness-of-fit indexes for testing measurement invariance. Structural Equation Modeling, 9(2), 233-255. https://doi.org/https://doi.org/10.1207/S15328007SEM0902_5

CITO B.V. (2013). Toets 3 Nederlandse leesvaardigheid taak 1 en 2 [Test 3 Dutch reading skills assignment 1 and 2]. Arnhem. 
Conradi, K., Jang, B. G., \& McKenna, M. C. (2014). Motivation terminology in reading research: A conceptual review. Educational Psychology Review, 26(1), 127-164. https://doi.org/10.1007/s10648-013-9245-z

De Naeghel, J., Van Keer, H., Vansteenkiste, M., Haerens, L., \& Aelterman, N. (2016). Promoting elementary school students' autonomous reading motivation: Effects of a teacher professional development workshop. Journal of Educational Research, 109(3), 232-252. https://doi.org/10.1080/00220671.2014.942032

De Naeghel, J., Van Keer, H., Vansteenkiste, M., \& Rosseel, Y. (2012). The relation between elementary students' recreational and academic reading motivation, reading frequency, engagement, and comprehension: A self-determination theory perspective. Journal of Educational Psychology, 104(4), 1006-1021. https://doi.org/10.1037/a0027800

De Smedt, F., Heirweg, S., Rogiers, A., \& Merchie, E. (2020). Assessing and mapping reading and writing motivation in third to eight graders: A self-determination theory perspective. Frontiers in Psychology, 11, 1-17. https://doi.org/10.3389/fpsyg.2020.01678

Denton, C. A., Wolters, C. A., York, M. J., Swanson, E., Kulesz, P. A., \& Francis, D. J. (2015). Adolescents' use of reading comprehension strategies: Differences related to reading proficiency, grade level, and gender. Learning and Individual Differences, 37, 81-95. https://doi.org/10.1016/j.lindif.2014.11.016

Departement Onderwijs \& Vorming [Department of Education and Training]. (2019). Vlaams onderwijs in cijfers 2018-2019. https://www.onderwijs.vlaanderen.be

Dockx, J., De Fraine, B., \& Vandecandelaere, M. (2019). Does the track matter? A comparison of students' achievement in different tracks. Journal of Educational Psychology, 111(5), 827846. https://doi.org/10.1037/edu0000305 
European Commission. (2006). Recommendation of the European Parliament and the Council of 18 December 2006 on key competencies for lifelong learning. http://eur-lex.europa.eu/

Fredricks, J. A., Blumenfeld, P. C., \& Paris, A. H. (2004). School engagement: Potential of the concept, state of the evidence. Review of Educational Research, 74(1), 59-109. https://doi.org/10.3102/00346543074001059

Guthrie, J. T., Wigfield, A., Barbosa, P., Perencevich, K. C., Taboada, A., Davis, M. H., Scafiddi, N. T., \& Tonks, S. (2004). Increasing reading comprehension and engagement through conceptoriented reading instruction. Journal of Educational Psychology, 96(3), 403-423. https://doi.org/10.1037/0022-0663.96.3.403

Guthrie, J. T., Wigfield, A., Metsala, J. L., \& Cox, K. E. (1999). Motivational and cognitive predictors of text comprehension and reading amount. Scientific Studies of Reading, 3(3), 231-256. https://doi.org/10.1207/s1532799xssr0303_3

Hu, L. T., \& Bentler, P. M. (1999). Cutoff criteria for fit indexes in covariance structure analysis: Conventional criteria versus new alternatives. Structural Equation Modeling, 6(1), 1-55. https://doi.org/10.1080/10705519909540118

Jerrim, J., Lopez-Agudo, L. A., \& Marcenaro-Gutierrez, O. D. (2020). Does it matter what children read? New evidence using longitudinal census data from Spain. Oxford Review of Education. https://doi.org/10.1080/03054985.2020.1723516

Jorgensen. (2018). semTools: Useful tools for structural equation modeling. http://cran.rproject.org/package=semTools

Katzir, T., Lesaux, N. K., \& Kim, Y. S. (2009). The role of reading self-concept and home literacy practices in fourth grade reading comprehension. Reading and Writing, 22(3), 261-276. https://doi.org/10.1007/s11145-007-9112-8 
Klauda, S. L., \& Guthrie, J. T. (2014). Comparing relations of motivation, engagement, and achievement among struggling and advanced adolescent readers. Reading and Writing, 28(2), 239-269. https://doi.org/10.1007/s11145-014-9523-2

Kline, R. B. (2012). Principles and practice of structural equation modeling (D. A. Kenny \& T. D. Little (Eds.); 4th ed.). The Guilford Press.

Kozminsky, E., \& Kozminsky, L. (2001). How do general knowledge and reading strategies ability relate to reading comprehension of high school students at different educational levels? Journal of Research in Reading, 24(2), 187-204. https://doi.org/10.1111/1467-9817.00141

Lau, K. -L. (2006). Reading strategy use between Chinese good and poor readers: A think-aloud study. Journal of Research in Reading, 29(4), 383-399. https://doi.org/10.1111/j.14679817.2006.0302.x

Martin, M. O., Mullis, I. V. S., \& Kennedy, A. M. (2007). PIRLS 2006 technical report. TIMMS \& PIRLS International Study Center. https://timssandpirls.bc.edu/pirls2006/tech_rpt.html

McNamara, D. S., \& Magliano, J. (2009). Towards a comprehensive model of comprehension. In B. Ross (Ed.), The psychology of learning and motivation (Vol. 51, pp. 297-384). Academia Press.

Merchie, E., \& Van Keer, H. (2014). Using on-line and off-line measures to explore fifth and sixth graders' text-learning strategies and schematizing skills. Learning and Individual Differences, 32, 193-203. https://doi.org/10.1016/j.lindif.2014.03.012

Mokhtari, K., Dimitrov, D. M., \& Reichard, C. A. (2018). Revising the metacognitive awareness of reading strategies inventory (MARSI) and testing for factorial invariance. Studies in Second Language Learning and Teaching, 8(2), 219-246. https://doi.org/10.14746/ssllt.2018.8.2.3

Mokhtari, K., \& Reichard, C. A. (2002). Assessing students' metacognitive awareness of reading strategies. Journal of Educational Psychology, 94(2), 249-259. https://doi.org/10.1037/00220663.94.2.249 
Mol, S. E., \& Bus, A. G. (2011). To read or not to read: A meta-analysis of print exposure from infancy to early adulthood. Psychological Bulletin, 137(2), 267-296.

https://doi.org/10.1037/a0021890

Mol, S. E., \& Jolles, J. (2014). Reading enjoyment amongst non-leisure readers can affect achievement in secondary school. Frontiers in Psychology, 5, 1-10. https://doi.org/10.3389/fpsyg.2014.01214

Muthén, B. O., \& Satorra, A. (1995). Complex sample data in structural equation modeling. Sociological Methodology, 25, 267-316. https://doi.org/10.2307/271070

OECD. (2019a). Education at a glance 2019: OECD indicators. https://doi.org/10.1787/d85aa8cf-zh

OECD. (2019b). PISA 2018 results (Volume I): What students know and can do. https://doi.org/10.1787/5f07c754-en

Paris, S. G., Lipson, M. Y., \& Wixson, K. K. (1983). Becoming a strategic reader. Contemporary Educational Psychology, 8, 293-316. https://doi.org/0361-476X/83

Reeve, J., Jang, H., Carrell, D., Jeon, S., \& Barch, J. (2004). Enhancing students' engagement by increasing teachers' autonomy support. Motivation and Emotion, 28(2), 147-170. https://doi.org/0146-7239/04/0600-0147/0

Retelsdorf, J., Becker, M., Olaf, K., \& Möller, J. (2012). Reading development in a tracked school system: A longitudinal study over 3 years using propensity score matching. British Journal of Educational Psychology, 82, 647-671. https://doi.org/10.1111/j.2044-8279.2011.02051.x

Retelsdorf, J., Köller, O., \& Möller, J. (2011). On the effects of motivation on reading performance growth in secondary school. Learning and Instruction, 21(4), 550-559. https://doi.org/10.1016/j.learninstruc.2010.11.001 
Retelsdorf, J., Köller, O., \& Möller, J. (2014). Reading achievement and reading self-concept-Testing the reciprocal effects model. Learning and Instruction, 29, 21-30. https://doi.org/10.1016/j.learninstruc.2013.07.004

Roeschl-Heils, A., Schneider, W., \& Van Kraayenoord, C. E. (2003). Reading, metacognition and motivation: A follow-up study of German students in grades 7 and 8. European Journal of Psychology of Education, 18(1), 75-86. https://doi.org/10.1007/BF03173605

Rogiers, A., Merchie, E., \& Van Keer, H. (2019). Learner profiles in secondary education: Occurrence and relationship with performance and student characteristics. The Journal of Educational Research, 112(3), 1-12. https://doi.org/10.1080/00220671.2018.1538093

Rosseel, Y. (2010). Lavaan: An R package for structural equation modeling and more. Journal of Statistical Software, 48(2), 1-36.

Ryan, R. M., \& Deci, E. L. (2020). Intrinsic and extrinsic motivation from a self-determination theory perspective: Definitions, theory, practices, and future directions. Contemporary Educational Psychology, 61(April). https://doi.org/10.1016/j.cedpsych.2020.101860

Satorra, A., \& Bentler, P. M. (2001). A scaled difference chi-square test statistic for moment structure analysis. Psychometrika, 66(4), 507-514. https://doi.org/0033-3123/2001-4/1999-0759-A $\$ 00.75 / 0$

Schaffner, E., Philipp, M., \& Schiefele, U. (2016). Reciprocal effects between intrinsic reading motivation and reading competence? A cross-lagged panel model for academic track and nonacademic track students. Journal of Research in Reading, 39(1), 19-36. https://doi.org/10.1111/1467-9817.12027

Schiefele, U., Schaffner, E., Möller, J., Wigfield, A., Nolen, S., \& Baker, L. (2012). Dimensions of reading motivation and their relation to reading behavior and competence. Reading Research Quarterly, 47(4), 427-463. https://doi.org/10.1002/RRQ.030 
Schreiber, J. B., Stage, F. K., King, J., Nora, A., \& Barlow, E. A. (2006). Reporting structural equation modeling and confirmatory factor analysis results: A review. Journal of Educational Research, 99(6), 323-337. https://doi.org/10.3200/JOER.99.6.323-338

Skinner, E. A., Wellborn, J., \& Connell, J. (1990). What it takes to do well in school and whether I've got it: The role of perceived control in children's engagement and school achievement. Journal of Educational Psychology, 82(1), 22-32. https://doi.org/10.1037//0022-0663.82.1.22

Sobel, M. E. (1986). Some new results on indirect effects and their standard errors in covariance structure models. Sociological Methodology, 16, 159-186. https://www.jstor.org/stable/270922

Stapleton, L. M. (2006). An assessment of practical solutions for structural equation modeling with complex sample data. Structural Equation Modeling, 13(1), 28-58. https://doi.org/10.1207/s15328007sem1301

Taboada, A., Tonks, S. M., Wigfield, A., \& Guthrie, J. T. (2009). Effects of motivational and cognitive variables on reading comprehension. Reading and Writing, 22(1), 85-106. https://doi.org/10.1007/s11145-008-9133-y

Toste, J., Didion, L., Peng, P., \& Filderman, M. (2020). A meta-analytic review of the relations between motivation and reading achievement for K-12 students. Review of Educational Research, 90(3). https://doi.org/https://doi.org/10.3102/0034654320919352

Vansteenkiste, M., Zhou, M., Lens, W., \& Soenens, B. (2005). Experiences of autonomy and control among Chinese learners: Vitalizing or immobilizing? Journal of Educational Psychology, 97(3), 468-483. https://doi.org/10.1037/0022-0663.97.3.468

Veenman, M. V. J. (2011). Alternative assessment of strategy use with self-report instruments: A discussion. Metacognition and Learning, 6(2), 205-211. https://doi.org/10.1007/s11409-0119080-x 
Wang, J. H., \& Guthrie, J. T. (2004). Modeling the effects of intrinsic motivation, extrinsic motivation, amount of reading, and past reading achievement on text comprehension between U.S. and Chinese students. Reading Research Quarterly, 39(2), 162-186.

https://doi.org/https://doi.org/10.1598/RRQ.39.2.2

Wharton-McDonald, R., \& Swiger, S. (2009). Developing higher order comprehension in the middle grades. In S. E. Isreal \& G. G. Duffy (Eds.), Handbook of research on reading comprehension (pp. 531-550). Routledge.

Wigfield, A., Guthrie, J. T., Perencevisch, K. C., Taboada, A., Klauda, S. L., McRae, A., \& Barbosa, P. (2008). Role of reading engagement in mediating effects of reading comprehension instruction on reading outcomes. Psychology in the Schools, 45(5), 432-445. https://doi.org/10.1002/pits

Wolters, C. A., Denton, C. A., York, M. J., \& Francis, D. J. (2014). Adolescents' motivation for reading: Group differences and relation to standardized achievement. Reading and Writing, 27(3), 503-533. https://doi.org/10.1007/s11145-013-9454-3 


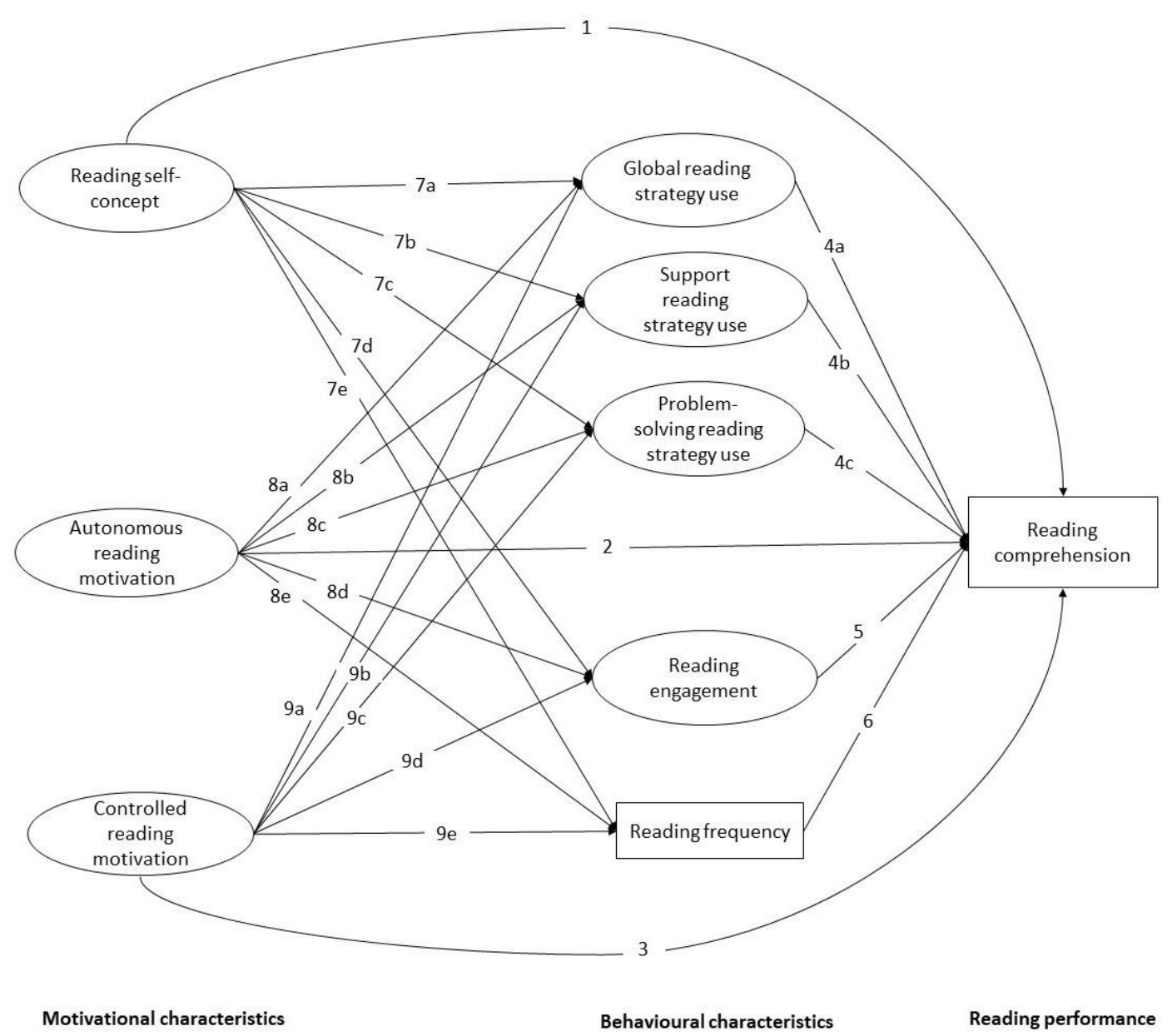

Figure 1: Hypothesized Model Relating Motivational and Behavioural Characteristics to Reading comprehension 


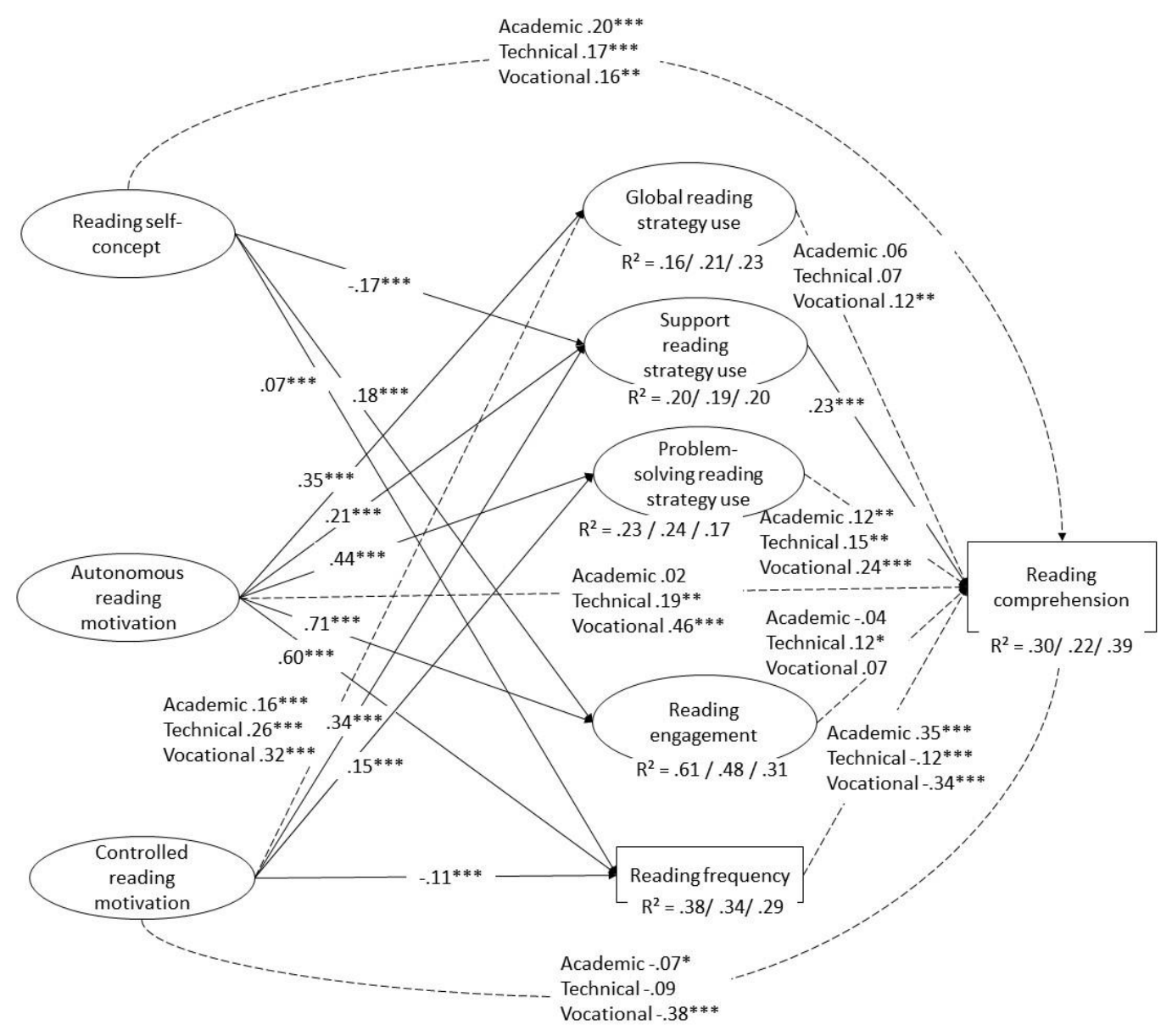

Motivational characteristics

Behavioural characteristics

Reading performance

Figure 2: Significant Parameter Estimates of the Structural Model Across Educational Tracks

$* \mathrm{p}<.05, * * \mathrm{p}<.01, * * * \mathrm{p}<.001$ two-tailed 
Table 1

Overview of Measures: Format, Answer Options, Number of Items, Example Item

\begin{tabular}{|c|c|c|c|c|}
\hline Measure & Format & Answer options & $\begin{array}{l}\text { Number } \\
\text { of items }\end{array}$ & Example item \\
\hline $\begin{array}{l}\text { Reading self- } \\
\text { concept }\end{array}$ & $\begin{array}{l}\text { 4-point } \\
\text { Likert-type } \\
\text { scale }\end{array}$ & $\begin{array}{l}\text { I do not agree }- \text { I } \\
\text { agree }\end{array}$ & 5 & $\begin{array}{l}\text { Reading is harder for me than for } \\
\text { many of my classmates }\end{array}$ \\
\hline $\begin{array}{l}\text { Reading } \\
\text { motivation: }\end{array}$ & $\begin{array}{l}\text { 5-point } \\
\text { Likert scale }\end{array}$ & $\begin{array}{l}\text { I do not agree at all } \\
\text { - I definitely agree }\end{array}$ & & I read because... \\
\hline Autonomous & & & 8 & I enjoy reading \\
\hline Controlled & & & 9 & I feel guilty when I do not read \\
\hline $\begin{array}{l}\text { Reading strategy } \\
\text { use: }\end{array}$ & $\begin{array}{l}\text { 5-point } \\
\text { Likert scale }\end{array}$ & $\begin{array}{l}\text { Never or almost } \\
\text { never - always or } \\
\text { almost always }\end{array}$ & & $\begin{array}{l}\text { How frequently do you use these } \\
\text { strategies? }\end{array}$ \\
\hline Global & & & 5 & I have a purpose in mind when I read \\
\hline Support & & & 5 & $\begin{array}{l}\text { I take notes while reading to help me } \\
\text { understand what I read }\end{array}$ \\
\hline Problem-solving & & & 4 & $\begin{array}{l}\text { I try to guess the meaning of } \\
\text { unknown words or phrases }\end{array}$ \\
\hline $\begin{array}{l}\text { Reading } \\
\text { engagement }\end{array}$ & $\begin{array}{l}\text { Bipolar } \\
\text { format }\end{array}$ & $1-2-3-4-5-6-7$ & 4 & $\begin{array}{l}\text { My attention is dispersed during } \\
\text { reading - my attention is focused } \\
\text { during reading }\end{array}$ \\
\hline Reading frequency & $\begin{array}{l}\text { 4-point } \\
\text { Likert-type } \\
\text { scale }\end{array}$ & $\begin{array}{l}\text { Never - every day } \\
\text { or almost every day }\end{array}$ & 1 & $\begin{array}{l}\text { How often do you read in your free } \\
\text { time? }\end{array}$ \\
\hline
\end{tabular}


Table 2

Overview of Measures: Confirmatory Factor Analysis, Measurement Invariance, Internal Consistency

\begin{tabular}{|c|c|c|c|c|c|}
\hline \multirow[t]{2}{*}{ Measure } & \multicolumn{3}{|c|}{ Confirmatory factor analysis $^{1}$} & \multirow{2}{*}{$\begin{array}{l}\text { Measurement } \\
\text { invariance }^{2} \\
\Delta \mathrm{CFI}\end{array}$} & \multirow{2}{*}{$\begin{array}{l}\text { Internal consistency } \\
\text { Bentler's rho }\end{array}$} \\
\hline & CFI & RMSEA & SRMR & & \\
\hline $\begin{array}{l}\text { Reading self- } \\
\text { concept }\end{array}$ & 1.00 & .00 & .04 & .010 & .74 \\
\hline Reading motivation & .94 & .08 & .06 & .003 & $\begin{array}{l}\text { Autonomous } .95 \\
\text { Controlled } .79\end{array}$ \\
\hline $\begin{array}{l}\text { Reading strategy } \\
\text { use }\end{array}$ & .94 & .06 & .04 & .010 & $\begin{array}{l}\text { Global .67 } \\
\text { Support .69 } \\
\text { Problem-solving .69 }\end{array}$ \\
\hline $\begin{array}{l}\text { Reading } \\
\text { engagement }\end{array}$ & .99 & .06 & .02 & .008 & .71 \\
\hline Reading frequency & .94 & .06 & .04 & .010 & .72 \\
\hline
\end{tabular}

\footnotetext{
${ }^{1}$ Several fit indexes are used to evaluate the fit of confirmatory factor models and structural equation models. First, the CFI. According to Browne and Cudeck (1992), a CFI-value above .90 indicates an adequate fit. Second, the RMSEA. This value should be close to .06 for an acceptable fit (Hu \& Bentler, 1999) and below .08 for a reasonable fit (Schreiber et al., 2006). Finally, the SRMR should be below .08 to indicate a reasonable fit (Hu \& Bentler, 1999).

${ }^{2}$ A difference in CFI between a model with no constraints and a model with two constraints (equal loadings and intercepts) smaller than or equal to .01 indicates strong measurement invariance (Chueng \& Rensvold, 2002). ${ }^{3}$ An internal consistency between .60-.75 is regarded moderate, .75-.85 good and larger than .85 excellent (Bentler, 2009).
} 
Table 3

Total and Descriptive Statistics per Educational Track

\begin{tabular}{|c|c|c|c|c|c|c|c|}
\hline $\begin{array}{l}\frac{0}{0} \\
\frac{0}{\frac{0}{2}} \\
\frac{\pi}{>}\end{array}$ & 气气 & 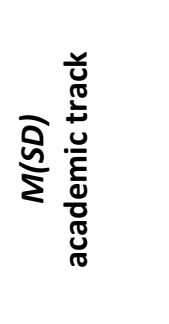 & 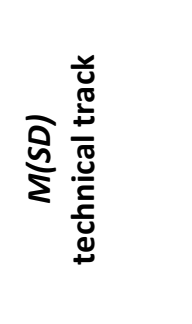 & 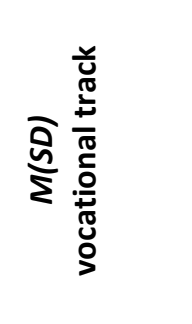 & 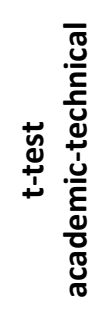 & 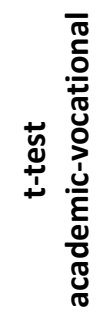 & 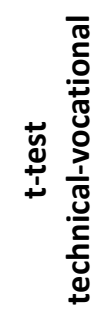 \\
\hline $\begin{array}{l}\text { Reading } \\
\text { comprehension }\end{array}$ & $.00(.89)$ & $.50(.72)$ & $-.32(.68)$ & $-.95(.63)$ & $\begin{array}{l}25.45 \\
* * *\end{array}$ & $\begin{array}{l}38.79 \\
* * *\end{array}$ & $\begin{array}{l}15.55 \\
* * *\end{array}$ \\
\hline $\begin{array}{l}\text { Reading self- } \\
\text { concept }\end{array}$ & $3.10(.64)$ & $3.22(.60)$ & $3.01(.65)$ & $2.91(.72)$ & $\begin{array}{l}7.44 \\
* * *\end{array}$ & $\begin{array}{l}7.81 \\
* * *\end{array}$ & $\begin{array}{l}2.25 \\
*\end{array}$ \\
\hline $\begin{array}{l}\text { Autonomous } \\
\text { reading } \\
\text { motivation }\end{array}$ & $2.56(1.22)$ & $2.90(1.20)$ & $2.23(1.14)$ & $2.12(1.10)$ & $\begin{array}{l}12.49 \\
* * *\end{array}$ & $\begin{array}{l}12.04 \\
* * *\end{array}$ & 1.56 \\
\hline $\begin{array}{l}\text { Controlled } \\
\text { reading } \\
\text { motivation }\end{array}$ & $1.72(.68)$ & $1.73(.66)$ & $1.66(.63)$ & $1.81(.81)$ & $\begin{array}{l}2.15 \\
*\end{array}$ & -1.95 & $\begin{array}{l}-3.51 \\
* * *\end{array}$ \\
\hline $\begin{array}{l}\text { Global reading } \\
\text { strategy use }\end{array}$ & $2.82(.78)$ & $2.93(.74)$ & $2.76(.75)$ & $2.62(.89)$ & $\begin{array}{l}5.08 \\
* * *\end{array}$ & $\begin{array}{l}6.43 \\
* * *\end{array}$ & $\begin{array}{l}2.74 \\
* *\end{array}$ \\
\hline $\begin{array}{l}\text { Support reading } \\
\text { strategy use }\end{array}$ & $2.23(.78)$ & $2.27(.73)$ & $2.20(.78)$ & $2.15(.91)$ & $\begin{array}{l}2.05 \\
*\end{array}$ & $\begin{array}{l}2.34 \\
*\end{array}$ & 0.88 \\
\hline $\begin{array}{l}\text { Problem-solving } \\
\text { reading strategy } \\
\text { use }\end{array}$ & $3.31(.82)$ & $3.50(.73)$ & $3.21(.78)$ & $2.91(.95)$ & $\begin{array}{l}8.16 \\
* * *\end{array}$ & $\begin{array}{l}11.21 \\
* * *\end{array}$ & $\begin{array}{l}5.37 \\
* * *\end{array}$ \\
\hline $\begin{array}{l}\text { Reading } \\
\text { engagement }\end{array}$ & $3.97(1.18)$ & $4.22(1.05)$ & $3.75(1.15)$ & $3.55(1.40)$ & $\begin{array}{l}9.34 \\
* * *\end{array}$ & $\begin{array}{l}8.90 \\
* * *\end{array}$ & $\begin{array}{l}2.48 \\
*\end{array}$ \\
\hline $\begin{array}{l}\text { Reading } \\
\text { frequency }\end{array}$ & $1.27(1.18)$ & 1.52 (1.17) & $1.07(1.13)$ & $.86(1.13)$ & $\begin{array}{l}8.62 \\
* * *\end{array}$ & $\begin{array}{l}10.08 \\
* * *\end{array}$ & $\begin{array}{l}2.99 \\
* *\end{array}$ \\
\hline
\end{tabular}

${ }^{*} p<.05,{ }^{* *} p<.01, * * * p<.001$, two-tailed 


\section{Table 4}

Correlations Among the Variables Included in the Study

\begin{tabular}{|c|c|c|c|c|c|c|c|c|c|}
\hline & 1 & 2 & 3 & 4 & 5 & 6 & 7 & 8 & 9 \\
\hline $\begin{array}{l}\text { 1. Reading } \\
\text { comprehension }\end{array}$ & - & & & & & & & & \\
\hline 2. Reading self-concept & $.34 * *$ & - & & & & & & & \\
\hline $\begin{array}{l}\text { 3. Autonomous reading } \\
\text { motivation }\end{array}$ & $.37^{* *}$ & $.26^{* *}$ & - & & & & & & \\
\hline $\begin{array}{l}\text { 4. Controlled reading } \\
\text { motivation }\end{array}$ & $-.11^{* *}$ & $-.12 * *$ & $.21 * *$ & - & & & & & \\
\hline 5. Reading engagement & $.28 * *$ & $.28 * *$ & $.53 * *$ & $.11^{* *}$ & - & & & & \\
\hline 6. Reading frequency & $.33^{* *}$ & $.24^{* *}$ & $.59 * *$ & .03 & $.40 * *$ & - & & & \\
\hline $\begin{array}{l}\text { 7. Global reading } \\
\text { strategies }\end{array}$ & $.13^{* *}$ & $.09 * *$ & $.31 * *$ & $.21 * *$ & $.29 * *$ & $.20 * *$ & - & & \\
\hline $\begin{array}{l}\text { 8. Support reading } \\
\text { strategies }\end{array}$ & $-.08 * *$ & $-.13^{* *}$ & $.19 * *$ & $.29 * *$ & $.16^{* *}$ & $.07 * *$ & $.45^{* *}$ & - & \\
\hline $\begin{array}{l}\text { 9. Problem-solving } \\
\text { reading strategies }\end{array}$ & $.25 * *$ & $.10 * *$ & $.41 * *$ & $.18^{* *}$ & $.37 * *$ & $.27 * *$ & $.49 * *$ & $.43 * *$ & - \\
\hline
\end{tabular}

$* * p<.01$, two-tailed 
Table 5

MG-SEM: Comparison of Differences Across Educational Tracks

\begin{tabular}{|c|c|c|c|c|c|c|}
\hline Model & SB $\chi^{2}$ & $d f$ & $\begin{array}{l}\text { Reference } \\
\text { model }\end{array}$ & $\Delta \chi^{2}$ & $\Delta d f$ & $\mathbf{p}$ \\
\hline $1^{a}$ & 7335.76 & 2500 & & & & \\
\hline $2^{b}$ & 7936.36 & 2546 & Model 1 & 600.61 & 46 & $.00 * * *$ \\
\hline \multicolumn{7}{|c|}{$\begin{array}{l}\text { Adjustments to Model 2: allowing each regression coefficient separately to vary across educ } \\
\text { "Variable X } \rightarrow \text { variable Y": specific regression that is allowed to vary across educational tracks }\end{array}$} \\
\hline \multicolumn{7}{|c|}{ Motivational variables $\rightarrow$ reading comprehension } \\
\hline $\begin{array}{l}\text { Reading self-concept } \rightarrow \text { reading } \\
\text { comprehension }\end{array}$ & 7755.38 & 2544 & Model 2 & 180.98 & 2 & $.00 * * *$ \\
\hline $\begin{array}{l}\text { Autonomous reading motivation } \rightarrow \\
\text { reading comprehension }\end{array}$ & 7836.75 & 2544 & Model 2 & 99.62 & 2 & $.00 * * *$ \\
\hline $\begin{array}{l}\text { Controlled reading motivation } \rightarrow \\
\text { reading comprehension }\end{array}$ & 7924.70 & 2544 & Model 2 & 11.66 & 2 & $.00 * *$ \\
\hline \multicolumn{7}{|c|}{ Behavioural variables $\rightarrow$ reading comprehension } \\
\hline $\begin{array}{l}\text { Reading engagement } \rightarrow \text { reading } \\
\text { comprehension }\end{array}$ & 7842.23 & 2544 & Model 2 & 94.13 & 2 & $.00 * * *$ \\
\hline $\begin{array}{l}\text { Global reading strategy use } \rightarrow \text { reading } \\
\text { comprehension }\end{array}$ & 7855.62 & 2544 & Model 2 & 80.74 & 2 & $.00 * * *$ \\
\hline $\begin{array}{l}\text { Support reading strategy use } \rightarrow \text { reading } \\
\text { comprehension }\end{array}$ & 7935.08 & 2544 & Model 2 & 1.29 & 2 & .53 \\
\hline $\begin{array}{l}\text { Problem-solving reading strategy use } \rightarrow \\
\text { reading comprehension }\end{array}$ & 7751.21 & 2544 & Model 2 & 185.16 & 2 & $.00 * * *$ \\
\hline $\begin{array}{l}\text { Reading frequency } \rightarrow \text { reading } \\
\text { comprehension }\end{array}$ & 7547.27 & 2544 & Model 2 & 389.09 & 2 & $.00 * * *$ \\
\hline \multicolumn{7}{|l|}{ Reading self-concept $\rightarrow$ behavioural variables } \\
\hline $\begin{array}{l}\text { Reading self-concept } \rightarrow \text { reading } \\
\text { engagement }\end{array}$ & 7934.62 & 2544 & Model 2 & 1.75 & 2 & .42 \\
\hline $\begin{array}{l}\text { Reading self-concept } \rightarrow \text { global reading } \\
\text { strategy use }\end{array}$ & 7935.94 & 2544 & Model 2 & 0.43 & 2 & .81 \\
\hline $\begin{array}{l}\text { Reading self-concept } \rightarrow \text { support reading } \\
\text { strategy-use }\end{array}$ & 7934.77 & 2544 & Model 2 & 1.59 & 2 & .45 \\
\hline $\begin{array}{l}\text { Reading self-concept } \rightarrow \text { problem- } \\
\text { solving reading strategy-use }\end{array}$ & 7935.28 & 2544 & Model 2 & 1.09 & 2 & .58 \\
\hline $\begin{array}{l}\text { Reading self-concept } \rightarrow \text { reading } \\
\text { frequency }\end{array}$ & 7930.54 & 2544 & Model 2 & 5.82 & 2 & .05 \\
\hline \multicolumn{7}{|c|}{ Autonomous reading motivation $\rightarrow$ behavioural variables } \\
\hline $\begin{array}{l}\text { Autonomous reading motivation } \rightarrow \\
\text { reading engagement }\end{array}$ & 7935.91 & 2544 & Model 2 & 0.45 & 2 & .76 \\
\hline \multirow[t]{2}{*}{$\begin{array}{l}\text { Autonomous reading motiva } \\
\text { global reading strategy use }\end{array}$} & 7933.09 & 2544 & Model 2 & 3.28 & 2 & .19 \\
\hline & & & Model 2 & & & \\
\hline
\end{tabular}




\begin{tabular}{lcccccc}
\hline $\begin{array}{l}\text { Autonomous reading motivation } \rightarrow \\
\text { support reading strategy use }\end{array}$ & 7937.07 & 2544 & & 0.71 & 2 & .70 \\
$\begin{array}{l}\text { Autonomous reading motivation } \rightarrow \\
\text { problem-solving reading strategy use }\end{array}$ & 7933.04 & 2544 & Model 2 & 3.32 & 2 & .19 \\
$\begin{array}{l}\text { Autonomous reading motivation } \rightarrow \\
\text { reading frequency }\end{array}$ & 7933.46 & 2544 & Model 2 & 2.90 & 2 & .23 \\
$\begin{array}{l}\text { Controlled reading motivation } \rightarrow \text { behavioural variables } \\
\text { Controlled reading motivation } \rightarrow \text { global }\end{array}$ & 7929.41 & 2544 & Model 2 & 6.95 & 2 & $.03^{*}$ \\
$\begin{array}{l}\text { reading strategy use } \\
\text { Controlled reading motivation } \rightarrow\end{array}$ & 7936.47 & 2544 & Model 2 & 0.10 & 2 & .94 \\
$\begin{array}{l}\text { support reading strategy use } \\
\text { Controlled reading motivation } \rightarrow \\
\text { problem-solving reading strategy use }\end{array}$ & 7931.16 & 2544 & Model 2 & 5.21 & 2 & .07 \\
$\begin{array}{l}\text { Controlled reading motivation } \rightarrow \\
\text { reading engagement } \\
\text { Controlled reading motivation } \rightarrow\end{array}$ & 7933.46 & 2544 & Model 2 & 2.90 & 2 & .23 \\
reading frequency
\end{tabular}

${ }^{a}$ equal factor loadings and equal intercepts across educational tracks

${ }^{b}$ equal factor loadings, equal intercepts, and equal regression coefficients across educational tracks

$* \mathrm{p}<.05,{ }^{* *} \mathrm{p}<.01, * * * \mathrm{p}<.001$, two-tailed 


\section{Table 6}

Standardized Parameter Estimates Relating Motivational Variables to Reading Comprehension Mediated by Behavioural Variables

Indirect path

Motivational variable $\rightarrow$ behavioural variable $\rightarrow$ reading comprehension

\section{Standardised indirect relationship}

\begin{tabular}{|c|c|c|c|c|}
\hline \multicolumn{5}{|l|}{ Reading self-concept } \\
\hline Reading self-concept $\rightarrow$ reading engagement & -.01 & $.02 *$ & .01 & .01 \\
\hline Reading self-concept $\rightarrow$ support reading strategy use & $.02 *$ & $.08 * *$ & $.04^{*}$ & $.04 * *$ \\
\hline Reading self-concept $\rightarrow$ reading frequency & $.02 *$ & -.00 & -.06 & $.01^{*}$ \\
\hline \multicolumn{5}{|l|}{ Autonomous reading motivation } \\
\hline Autonomous reading motivation $\rightarrow$ reading engagement & -.03 & $.08^{*}$ & .04 & .03 \\
\hline $\begin{array}{l}\text { Autonomous reading motivation } \rightarrow \text { global reading strategy } \\
\text { use }\end{array}$ & .02 & .02 & $.04 * *$ & $.03 * *$ \\
\hline $\begin{array}{l}\text { Autonomous reading motivation } \rightarrow \text { support reading } \\
\text { strategy use }\end{array}$ & $-.03 * *$ & $-.06 *$ & $-.06 * *$ & $-.05^{* *}$ \\
\hline $\begin{array}{l}\text { Autonomous reading motivation } \rightarrow \text { problem-solving } \\
\text { reading strategy use }\end{array}$ & $.05^{* *}$ & $.07 * *$ & $.09 * * *$ & $.07^{* *}$ \\
\hline Autonomous reading motivation $\rightarrow$ reading frequency & $.21^{* * *}$ & $-.07 * *$ & $-.21 * * *$ & $.05^{* *}$ \\
\hline \multicolumn{5}{|l|}{ Controlled reading motivation } \\
\hline $\begin{array}{l}\text { Controlled reading motivation } \rightarrow \text { global reading strategy } \\
\text { use }\end{array}$ & .01 & .02 & $.04 * *$ & $.02 *$ \\
\hline $\begin{array}{l}\text { Controlled reading motivation } \rightarrow \text { support reading strategy } \\
\text { use }\end{array}$ & $-.04 * *$ & $-.16 * *$ & $-.09 * * *$ & $-.07 * *$ \\
\hline $\begin{array}{l}\text { Controlled reading motivation } \rightarrow \text { problem-solving reading } \\
\text { strategy use }\end{array}$ & $.01 *$ & $.03 * *$ & $.06 * *$ & $.02 * *$ \\
\hline Controlled reading motivation $\rightarrow$ reading frequency & $-.03 * *$ & .01 & $.08 * * *$ & $-.01 * *$ \\
\hline
\end{tabular}

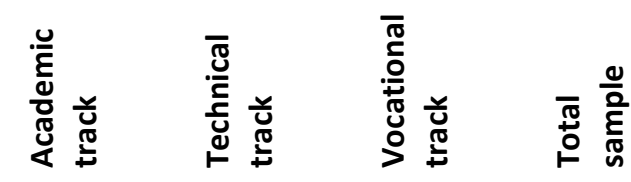

Autonomous reading motivation

Autonomous reading motivation $\rightarrow$ reading engagement

use

\section{strategy use}

Autonomous reading motivation $\rightarrow$ problem-solving

reading strategy use

Controlled reading motivation

Controlled reading motivation $\rightarrow$ global reading strategy

$* \mathrm{p}<.05, * * \mathrm{p}<.01, * * * \mathrm{p}<.001$, two-tailed 


\section{Appendix A}

Correlations Among the Variables Included in this Study

\begin{tabular}{|c|c|c|c|c|c|c|c|c|c|}
\hline & 1 & 2 & 3 & 4 & 5 & 6 & 7 & 8 & 9 \\
\hline 1. Reading comprehension & - & & & & & & & & \\
\hline \multirow[t]{3}{*}{ 2. Reading self-concept } & A: $.34^{* *}$ & - & & & & & & & \\
\hline & $\mathrm{T}: .26^{* *}$ & & & & & & & & \\
\hline & $\mathrm{V}: .21^{* *}$ & & & & & & & & \\
\hline 3. Autonomous reading & A: $.32^{* *}$ & A: $.25^{* *}$ & - & & & & & & \\
\hline \multirow[t]{2}{*}{ motivation } & $\mathrm{T}: .21^{* *}$ & $\mathrm{~T}: .20^{* *}$ & & & & & & & \\
\hline & $\mathrm{V}: .12^{* *}$ & V: .16** & & & & & & & \\
\hline \multirow[t]{3}{*}{ 4. Controlled reading motivation } & A: $-.18^{* *}$ & $A:-.12^{* *}$ & A: $.11^{* *}$ & - & & & & & \\
\hline & $\mathrm{T}:-.08 * *$ & $\mathrm{~T}:-.14^{* *}$ & $\mathrm{~T}: .27^{* *}$ & & & & & & \\
\hline & $\mathrm{V}:-.15^{* *}$ & $\mathrm{~V}:-.09$ & V: . $46^{* *}$ & & & & & & \\
\hline \multirow[t]{3}{*}{ 5. Reading engagement } & $A: .23^{* *}$ & A: $.30^{* *}$ & A: $.52 * *$ & A: .06* & - & & & & \\
\hline & $\mathrm{T}: .17^{* *}$ & $\mathrm{~T}: .21^{* *}$ & $\mathrm{~T}: .51^{* *}$ & $\mathrm{~T}: .15^{* *}$ & & & & & \\
\hline & V: .08 & $\mathrm{~V}: .21^{* *}$ & $V: .40^{* *}$ & $\mathrm{~V}: .16^{* *}$ & & & & & \\
\hline \multirow[t]{3}{*}{ 6. Reading frequency } & A: $.31^{* *}$ & $A: .24^{* *}$ & A: $.60 * *$ & A: -.03 & A: $.40 * *$ & - & & & \\
\hline & $\mathrm{T}: .19 * *$ & $\mathrm{~T}: .16^{* *}$ & $\mathrm{~T}: .54^{* *}$ & $\mathrm{~T}: .09 *$ & $\mathrm{~T}: .35^{* *}$ & & & & \\
\hline & $\mathrm{V}: .17^{* *}$ & V: .20** & V: . $48^{* *}$ & $V: .09$ & V: $.31^{* *}$ & & & & \\
\hline \multirow[t]{2}{*}{ 7. Global reading strategy use } & A: .06* & A: $.07 *$ & A: $.27^{* *}$ & A: $.13^{* *}$ & A: $.27^{* *}$ & A: $.17^{* *}$ & - & & \\
\hline & $\mathrm{T}: .02$ & $\mathrm{~T}: .05$ & $\mathrm{~T}: .25^{* *}$ & $\mathrm{~T}: .26^{* *}$ & $\mathrm{~T}: .29 * *$ & $\mathrm{~T}: .15^{* *}$ & & & \\
\hline
\end{tabular}


$\mathrm{V}:-.02 \quad \mathrm{~V}: .06 \quad \mathrm{~V}: .39^{* *} \quad \mathrm{~V}: .33^{* *} \quad \mathrm{~V}: .22^{* *} \quad \mathrm{~V}: .20^{* *}$

$\begin{array}{lllllllll}\text { 8. Support reading strategy use } & \mathrm{A}:-.12^{* *} & \mathrm{~A}:-.15^{* *} & \mathrm{~A}: .15^{* *} & \mathrm{~A}: .23^{* *} & \mathrm{~A}: .17^{* *} & \mathrm{~A}: .05 & \mathrm{~A}: .42^{* *} & - \\ & \mathrm{T}:-.15^{* *} & \mathrm{~T}:-.13^{* *} & \mathrm{~T}: .21^{* *} & \mathrm{~T}: .31^{* *} & \mathrm{~T}: .18^{* *} & \mathrm{~T}: .12^{* *} & \mathrm{~T}: .46^{* *} \\ & \mathrm{~V}:-.29^{* *} & \mathrm{~V}:-.17^{* *} & \mathrm{~V}: .21^{* *} & \mathrm{~V}: .39^{* *} & \mathrm{~V}: .08 & \mathrm{~V}:-.02 & \mathrm{~V}: .53^{* *} \\ & & & & & & & \\ & & & & & & \\ \text { 9. Problem-solving reading } & \mathrm{A}: .15^{* *} & \mathrm{~A}: .06^{*} & \mathrm{~A}: .33^{* *} & \mathrm{~A}: .12^{* *} & \mathrm{~A}: .33^{* *} & \mathrm{~A}: .23^{* *} & \mathrm{~A}: .44^{* *} & \mathrm{~A}: .39^{* *} \\ \text { strategy use } & \mathrm{T}: .09^{*} & \mathrm{~T}: .06 & \mathrm{~T}: .41^{* *} & \mathrm{~T}: .24^{* *} & \mathrm{~T}: .40^{* *} & \mathrm{~T}: .26^{* *} & \mathrm{~T}: .48^{* *} & \mathrm{~T}: .46^{* *} \\ & \mathrm{~V}: .07 & \mathrm{~V}: .04 & \mathrm{~V}: .40^{* *} & \mathrm{~V}: .29^{* *} & \mathrm{~V}: .25^{* *} & \mathrm{~V}: .18^{* *} & \mathrm{~V}: .52^{* *} & \mathrm{~V}: .47^{* *}\end{array}$

${ }^{*} \mathrm{p}<.05,{ }^{* *} \mathrm{p}<.01$, two-tailed $-\mathrm{A}=$ academic track, $\mathrm{T}=$ technical track, $\mathrm{V}=$ vocational track 